J. Product. \& Dev., 24(1): 63 - 75(2019)

\title{
ECOLOGICAL STUDIES ON Ceroplastes floridensis (Hemiptera: Coccidae) INFESTING TWO VARIETIES OF ORANGE TREES AT SHARKIA GOVERNORATE, EGYPT
}

\author{
A.M. Zaki ; H.M. El-Sharkawy**; F.S. El-Santil ${ }^{* * *}$ and Nahla A. Ezz" \\ 1- Plant Protection Research Institute, Agricultural Research Center, Zagazig, \\ Egypt. \\ 2- Plant Production Department, Faculty of Technology and Development, \\ Zagazig Univ., Egypt.
}

\begin{abstract}
Ecological studies of Ceroplastes floridensis Comstock (Coccidae: Hemiptera) were carried out during two successive years (2016 and 2017) on two varieties of orange trees in Hannout village, Kafr Saqer district, Sharkia Governorate, Egypt.

The obtained results revealed that the total number of alive stages population had four peaks of activity yearly in both Baladi and Valencia orange tree varieties. The total effects of a biotic factors (Temperature ${ }^{\circ} \mathrm{C}$, Relative humidity $\mathrm{RH} \%$, Sunshine hours and Light Intensity Lux.) under this study on the total numbers of alive stages population of the pest during the two successive years varied between positively and negatively significant in each of Baladi and Valencia Varieties, successively. The pest activity appeared by three overlapping annual generations in either the Baladi and Valencia varieties citrus trees.

Conclusively, from this results it could be concluded that the total number of stages of this insect was between three to four peaks per activity per year on both types of orange Balady and Valencia during both first and second years of the study.

Keywords: Ecological studies, Ceroplastes floridensis, annual generations, citrus trees, Egypt.
\end{abstract}

\section{INTRODUCTION}

Citrus trees (Orange fruits), Citrus sinensis sp. (Orange, Lemon and Mandarin) with sour favorable taste and nutritive value, considered as one of the most popular fruits in Egypt. It contains a high percent of sugar, protein, fats, salts and vitamins. It plays an important role in food industrialization such as juices and jams which wanted with large amounts to export according to 
good reputation of Egyptian varieties which gained popularity all over the world. Citrus trees represent recently one of the most economically cash crops in Egypt exports, which accounted for the largest share of exports, amounted to $1,554,241$ tons at the year 2017.

In Egypt, citrus is one of the most important fruits as their rich production and exportation potentials (El-Kassas, 1984).

Citrus is cultivated in all of the tropical and subtropical lands of the world, with production restricted primarily by the regularity and severity of winter frost, (Ebeling, 1959; Whiteside, 1988; Snowdon, 1990).

Economic Agricultural Report, from Central Administration for Economic Agriculture, Ministry of Agriculture, Egypt, 2008 reported that 5 districts in 4 Governorates ranked first in the total area and production of citrus fruit compared to other crops compared to the other Governorates. These districts were Nubaria, 141,563 feddans productive and the volume of production amounted 1,441,000 tons per a year, while El-Behara takes the second place with 639,385 tons. The report of the Ministry of Agriculture said that among the provinces of the production of El-Sharkia citrus fruit areas reached 54,455 acres and the amount of citrus fruit production amounted to 440 thousand and 364 tons, and the average per individual consumption of citrus in Egypt to about $37 \mathrm{~kg}$ per year, with the highest rate of citrus fruit consumption in other countries of citrus producers.

Scale insects are usually considered as the most important pests which infesting citrus trees in many countries of the world. Podoler et al. (1981) reported that Ceroplastes floridensis Comstock attacks a great number of host plants especially citrus spp., and its main damage is due to the production of honeydew, which serves a substance for various sooty mould fungi. Also, they stated that sever infestations of citrus may result in culling of the inter crop, reduction of subsequent yields and serious injury to the trees.

In Egypt, the first recorded of $C$. floridensis in 1905 on orange trees at kafer El-Dewar, El-Beheira (Willcocks, 1922), Then it became a common pest of citrus trees and ornamental plants during the last few years, especially the humid areas at the northern of Egypt (Mesbah et al., 2001). Hall (1923) mentioned that it was common in Lower Egypt, particularly in Alexandria and the coastal areas. Moustafa (2012) surveyed scale insects (Coccoidae: Hemiptera) infested citrus trees with a key of these pests in Egypt, also her work indicated that citrus wax scale, $C$. floridensis Comstock has two peaks the first in May and the second in October. Omar (2013) stated that, the Florida wax scale, $C$. floridensis infesting four varieties of citrus all over the year. Its ratio on Mandarin was higher than the other varieties in the first year of study but in the second year, the highest number was observed on Baladi orange. 


\section{MATERIALS AND METHODS}

Field experiments were carried out in citrus farm in Hannout village, Kafr Saqer district, Sharkia Governorate, Egypt. This study was continued during two successive years, from January 2016 to December 2017. The farm received normal agricultural practices and no chemical control was applied. The study was conducted in an area of about four feddan for citrus varieties Orange Baladi (Citrus sinensis var. Baladi) and Orange Valencia (Citrus sinensis var. Valencia). Five trees were selected and labeled from each variety. These trees were nearly similar in size, age and vegetation. Each tree was divided into four main directions (east, west, north and south) and center core.

For sampling, five leaves were picked up at random twice monthly from each direction, i.e. 250 leaves per sample ( 2 times monthly $\mathrm{x} 5$ trees $\mathrm{x} 5$ directions $\mathrm{x} 5$ leaves of the tree). The samples were put in polyethylene bags and transferred into the laboratory for carefully inspection. These samples were examined in the same day using a stereomicroscope whereas the different alive and non-alive stages of $C$. floridensis were counted and recorded.

The prevailing means of air temperature $\left({ }^{\circ} \mathrm{C}\right)$, relative humidity $(\mathrm{RH} \%)$ and sunshine (hrs.) in the experimental area during the periods of the present study were obtained from the Central Laboratory for Agricultural Meteorology, Agricultural Research Center, Ministry of Agriculture. Light intensity (Lux) in outer zone of the trees was measured at the sampling days using Luxmeter at mid-day (12 a.m.), when the sunlight was perpendicular with the earth to obtain the highest light intensity. The relationships between the tested climatic factors and each adult, nymphs, insect total population density and mortality $\%$ were studied. Simple correlation and partial regression values were calculated using COSTAT Computer Program (2005).

To detect the effect of the cardinal directions on the distribution of scale insects and its associated with natural enemies mathematically, the following formula was used.

$$
\mathrm{H}=\sqrt{\mathrm{F}_{1}^{2}+\mathrm{F}_{2}^{2}+2 \mathrm{~F} \mathrm{~F}_{2} \operatorname{Cos} \mathrm{Q}}
$$

This angle was calculated by dividing $\mathrm{F}_{2} / \mathrm{F}_{1}$, Mahmoud (1981) and Hassan (1998):

$\mathrm{H}=$ Powers summation

$\mathrm{F}_{1}=$ The population on the east (E) minus the population on the west (W) if the first is higher and reversed it if the latter is higher.

$\mathrm{F}_{2}=$ The population on the north $(\mathrm{N})$ minus the population on the south $(\mathrm{S})$ if the first is higher and the reverse is applied if the population on the south is higher. 
The figure obtained represents the tangent, the corresponding values of which was obtained from the mathematical.

$$
\mathrm{F}_{1}=\mathrm{E}-\mathrm{W} \quad \mathrm{F}_{2}=\mathrm{N}-\mathrm{S} \quad \text { Tan } \mathrm{Q}=\mathrm{F}_{2} / \mathrm{F}_{1}
$$

\section{RESULTS AND DISCUSSION}

\section{Seasonal abundance:}

\subsection{Total number of alive stages (Population density):}

As shown from obtained data in Table (1) in the Baladi variety of citrus trees during two years of the study, the total number of alive stages population indicated to four peaks in both years of study. The peaks were in February, May, July and October with 497, 1319, 915 and 562 individuals during 2016, respectively. In the second year it were in January, April, July and October with 302, 592, 1293 and 605 individuals, respectively. Generally, the total number of alive stages population during the second year (6304 individuals) was obviously higher in comparison with that during the first year (5894 individuals). Data in Table (2) revealed that the total number of alive stages population in the Valencia variety of citrus trees showed four peaks in February, April, July and October with 194, 379, 226 and 499 individuals during the first year, respectively. In the second year it were in January, May, August and October with 209, 478, 495 and 781 individuals, respectively. In general, the total number of alive stages population during the second year (4048 individuals) was clearly higher as compared with that during the first one (2837 individuals).

These results are in agreement with the findings of (Abd El-Fatah et al., 1991; Hendawy, 1999; Ghanim, 2003; El-Sherbenie, Merfat 2004; Moustafa, 2012 and Omar, 2013) they reported that the total population density peaks of the insect occurred during different periods of the year, the population peaks differed from each host fruit variety infested with this pest and it were varied from the month to month in each year of occurrence for the total population peaks. Also, these results where similar with El-Agamy (1994), who reported that the population of $C$. floridensis had four peaks of abundance in April, July, September and December. Also, these results go with the findings of Salem and Hamdy (1985), they recorded three peaks per year for this insect during January, June and November, respectively.

\subsection{Percentages of total mortality:}

Data in Table (1) showed that the percentages of total pest mortality on Baladi citrus variety trees during two years, indicated four peaks at June and August 2016 (57.53 and 72.4\%) and January and May 2017 (59.3 and 55.06\%). 
Table (1): Seasonal abundance of Ceroplastes floridensis Comstock on orange trees, variety Baladi, in Kafr Saqer district, during (2016) and (2017).

\begin{tabular}{|c|c|c|c|c|c|c|c|c|}
\hline \multirow{3}{*}{ Months } & \multicolumn{4}{|c|}{$\begin{array}{c}\text { Number of insects / } 250 \text { leaves monthly } \\
\text { at } 2016\end{array}$} & \multicolumn{4}{|c|}{$\begin{array}{l}\text { Number of insects / } 250 \text { leaves monthly } \\
\text { at } 2017\end{array}$} \\
\hline & \multicolumn{3}{|c|}{ Alive stages } & \multirow{2}{*}{$\begin{array}{c}\text { Natural } \\
\text { mortality } \\
\%\end{array}$} & \multicolumn{3}{|c|}{ Alive stages } & \multirow{2}{*}{$\begin{array}{c}\text { Natural } \\
\text { mortality } \\
\%\end{array}$} \\
\hline & Adults & Nymphs & $\begin{array}{l}\text { Population } \\
\text { density }\end{array}$ & & Adults & Nymphs & $\begin{array}{c}\text { Population } \\
\text { density }\end{array}$ & \\
\hline Jan. & 108 & 102 & 210 & 42.93 & 127 & 175 & 302 & 59.30 \\
\hline Feb. & 29 & 468 & 497 & 25.26 & 60 & 91 & 151 & 55.33 \\
\hline Mar. & 20 & 340 & 360 & 43.13 & 30 & 105 & 135 & 53.13 \\
\hline Apr. & 41 & 403 & 444 & 47.33 & 31 & 561 & 592 & 20.22 \\
\hline May & 65 & 1254 & 1319 & 14.85 & 55 & 402 & 457 & 55.06 \\
\hline Jun. & 96 & 465 & 561 & 57.53 & 78 & 629 & 707 & 38.09 \\
\hline Jul. & 135 & 780 & 915 & 29.23 & 118 & 1175 & 1293 & 7.71 \\
\hline Aug. & 62 & 60 & 122 & 72.40 & 107 & 606 & 713 & 31.05 \\
\hline Sep. & 36 & 74 & 110 & 71.79 & 49 & 274 & 323 & 46.44 \\
\hline Oct. & 53 & 509 & 562 & 18.67 & 47 & 558 & 605 & 18.57 \\
\hline Nov. & 102 & 288 & 390 & 40.73 & 85 & 370 & 455 & 42.98 \\
\hline Dec. & 190 & 214 & 404 & 40.85 & 201 & 370 & 571 & 36.70 \\
\hline Total & 937 & 4957 & 5894 & & 988 & 5316 & 6304 & \\
\hline Mean & 78.08 & 413.08 & 491.17 & 38.19 & 82.33 & 443.00 & 525.33 & 35.34 \\
\hline $\begin{array}{l}\text { Meansl } \\
50 \text { leaves }\end{array}$ & 18.74 & 99.14 & 117.88 & & 19.76 & 106.32 & 126.08 & \\
\hline
\end{tabular}

The highest peaks were in August and January with 72.40 and $59.30 \%$ in first and second years, respectively. The mean percentage of total mortality during the first year $(38.19 \%)$ was relatively higher as compared with that during the seconds $(35.34 \%)$.

As shown from obtained data in Table (2) in Valencia orange, the percentages of total mortality took places in January (62.5\%), May (64.9\%), September $(55.73 \%)$ and December $(54.95 \%)$ during the first year 2016 with highest value reached $64.90 \%$ in May and it recorded four peaks during the second year 2017in February (63.46 \%), June (45.99\%), September (36.68 \%) and December $(51.76 \%)$. The mean percentage of insect total mortality during the first year $(43.84 \%)$ was relatively higher than that in the second year (34.32\%). These findings agree with Schneider et al., (1987), no significant density-dependent mortality was found and the key stage mortality was generally in the pre-ovipositional stage and also in the early nemphal stages. 
Table (2): Seasonal abundance of Ceroplastes floridensis Comstock on orange trees, variety Valencia orange, in Kafr Saqer district, during (2016) and (2017).

\begin{tabular}{|c|c|c|c|c|c|c|c|c|}
\hline \multirow{3}{*}{ Months } & \multicolumn{4}{|c|}{$\begin{array}{l}\text { Number of insects / } 250 \text { leaves monthly } \\
\text { at } 2016\end{array}$} & \multicolumn{4}{|c|}{$\begin{array}{c}\text { Number of insects / } 250 \text { leaves monthly } \\
\text { at } 2017\end{array}$} \\
\hline & \multicolumn{3}{|c|}{ Alive stages } & \multirow{2}{*}{$\begin{array}{c}\text { Natural } \\
\text { mortality } \\
\%\end{array}$} & \multicolumn{3}{|c|}{ Alive stages } & \multirow{2}{*}{$\begin{array}{c}\text { Natural } \\
\text { mortality } \\
\%\end{array}$} \\
\hline & Adults & Nymphs & $\begin{array}{c}\text { Population } \\
\text { density }\end{array}$ & & Adults & Nymphs & $\begin{array}{c}\text { Population } \\
\text { density }\end{array}$ & \\
\hline Jan. & 140 & 40 & 180 & 62.5 & 139 & 70 & 209 & 31.48 \\
\hline Feb. & 102 & 92 & 194 & 52.22 & 80 & 53 & 133 & 63.46 \\
\hline Mar. & 69 & 109 & 178 & 46.87 & 35 & 182 & 217 & 49.77 \\
\hline Apr. & 25 & 354 & 379 & 23.49 & 33 & 197 & 230 & 42.21 \\
\hline May & 21 & 118 & 139 & 64.9 & 52 & 426 & 478 & 24.07 \\
\hline Jun. & 24 & 80 & 104 & 58.06 & 65 & 154 & 219 & 45.99 \\
\hline Jul. & 40 & 186 & 226 & 8.87 & 96 & 122 & 218 & 36.01 \\
\hline Aug. & 57 & 70 & 127 & 54.64 & 155 & 340 & 495 & 19.77 \\
\hline Sep. & 44 & 157 & 201 & 55.73 & 100 & 266 & 366 & 36.68 \\
\hline Oct. & 101 & 398 & 499 & 20.42 & 65 & 716 & 781 & 13.42 \\
\hline Nov. & 144 & 243 & 387 & 34.07 & 190 & 265 & 455 & 32.19 \\
\hline Dec. & 115 & 108 & 223 & 54.95 & 102 & 145 & 247 & 51.76 \\
\hline Total & 882 & 1955 & 2837 & & 1112 & 2936 & 4048 & \\
\hline Mean & 73.50 & 162.92 & 236.42 & 43.84 & 92.67 & 244.67 & 337.33 & 34.32 \\
\hline $\begin{array}{c}\text { Means/ } \\
\mathbf{5 0} \\
\text { leaves } \\
\end{array}$ & 17.64 & 39.26 & 56.90 & & 22.24 & 58.72 & 80.74 & \\
\hline
\end{tabular}

\section{Effect of climatic factors:}

Data in Table (3) showed that in the effect of climatic factors on (population density \& mortality \%) of the pest on Baladi and Valencia varieties of citrus trees during two years 2016 - 2017.

\subsection{On Population density:}

With regard to Baladi variety, there were positive non-significant effects between population density and each of mean temperature, light intensity and sunshine hours whereas (r) values were $0.259,0.218$ and 0.351 at 2016, respectively. While at 2017, there were positively significant effects between population density and the same previous factors whereas (r) values were $0.642,0.704$ and 0.589 , respectively.

The results of Valencia variety was negative non-significant effects between population density and sunshine hours in both years of the study, whereas (r) values were -0.436 and -0.232 , respectively. During the first year, there was negative correlations between population density and mean temperature, whereas (r) values were -0.093, Although during the second year, there was negative correlations between total number of alive stages and R.H., 
Table (3): Correlation coefficient (r) on different stages of Ceroplastes floridensis on citrus trees, varieties Baladi and Valencia, in Kafr Saqer district, during the 2016 and 2017 years.

\begin{tabular}{|c|c|c|c|c|c|c|c|c|}
\hline & \multicolumn{2}{|c|}{ Temp. $\left({ }^{\circ} \mathrm{C}\right)$} & \multicolumn{2}{|c|}{ RH $(\%)$} & \multicolumn{2}{|c|}{ Light intensity (Lux) } & \multicolumn{2}{|c|}{ Sunshine (hrs.) } \\
\hline & $\begin{array}{c}\mathbf{1}^{\mathrm{st}} \text { year } \\
(\mathbf{2 0 1 6})\end{array}$ & $\begin{array}{l}2^{\text {nan }} \text { year } \\
(2017)\end{array}$ & $\begin{array}{l}1^{\text {st }} \text { year } \\
(2016)\end{array}$ & $\begin{array}{c}2^{\text {na }} \text { year } \\
(2017)\end{array}$ & $\begin{array}{l}1^{\text {st }} \text { year } \\
(2016)\end{array}$ & $\begin{array}{c}2^{\text {na }} \text { year } \\
(2017)\end{array}$ & $\begin{array}{l}1^{\text {st }} \text { year } \\
(2016)\end{array}$ & $\begin{array}{c}2^{\text {na }} \text { year } \\
(2017)\end{array}$ \\
\hline \multicolumn{9}{|c|}{ Orange variety Baladi } \\
\hline Adults & -0.279 & -0.235 & $0.293^{*}$ & $0.613^{*}$ & 0.216 & -0.082 & 0.009 & 0.150 \\
\hline Nymphs & 0.303 & $0.709^{* *}$ & -0.482 & -0.231 & 0.188 & $0.748^{* *}$ & 0.352 & $0.590 *$ \\
\hline Population density & 0.259 & $0.642 *$ & -0.435 & -0.123 & 0.218 & $0.704 *$ & 0.351 & $0.589 *$ \\
\hline Mortality \% & 0.278 & -0.527 & 0.041 & 0.083 & 0.158 & -0.541 & 0.370 & -0.313 \\
\hline \multicolumn{9}{|c|}{ Orange variety Valencia } \\
\hline Adults & $-0.807 * *$ & -0.083 & $0.658 *$ & $0.648 *$ & $-0.682 *$ & -0.084 & $-0.657^{*}$ & 0.083 \\
\hline Nymphs & 0.223 & 0.385 & 0.143 & -0.317 & 0.429 & 0.359 & -0.202 & -0.211 \\
\hline Population density & -0.093 & 0.361 & 0.381 & -0.145 & 0.148 & 0.378 & -0.436 & -0.232 \\
\hline Mortality \% & -0.271 & -0.481 & -0.227 & 0.279 & -0.369 & -0.570 & 0.006 & 0.136 \\
\hline
\end{tabular}

whereas (r) values was -0.145 . Similar findings were reported by Helmy et al., (1986), they considering monthly variations, the population density strongly correlated with the abiotic factors (temperature and relative humidity). Farag $e t$ al., (2014), findings agree with and cleared these study results, they reported that the increase in nymph numbers of $C$. floridensis occurred due to the increase in mean monthly temperature. the relationship gave a good fit to the data and the co-efficient of determination were R2 $=0.908$ for 2000 year and $\mathrm{R} 2=0.957$ for 2012 . $\mathrm{R}$ showed that the strong relationship was found.

\subsection{On mortality(\%):}

In the Baladi variety, no significant effects were recorded at (2016). While during 2017, there were negatively non-significant effects between mortality $\%$ and each of mean temperature, light intensity and sunshine whereas (r) values were $-0.527,-0.541$ and -0.313 , respectively.

For Valencia variety, there were negative non-significant effects between the mortality $\%$ and each of temperature, relative humidity and light intensity whereas (r) values were $-0.271,-0.227$ and -0.369 at 2016 , respectively. During the second year, no significant effects were noticed but negatively effects between mortality $\%$ and each of mean temperature and light intensity whereas (r) values were -0.481 and -0.570 , respectively. This suggestion agrees with Podoler et al. (1981) they reported that climatic factors, mainly high temperatures combined with low humidity, acted as the main mortality factors during the spring generation.

\section{Number of generations:}

As C. floridensis is known to have overlapping generations, it was necessary to utilize the formula proposed by Audemard and Milaire (1975) and 
emended by Jacob (1977) for estimating the number of generations and their annual durations. Data of monthly counts of nymphal stage were indicated on millimeter paper.

Data illustrated in Fig. (1) indicated that during the first year, $C$. floridensis had three overlapping generations annually on Baladi citrus trees variety. Generally, the generations lasted about three to four months. The first generation was during the period extended from the beginning of January till the mid of April. The second generation occupied the period from the beginning of May till the end of August. The third and powers one occurred from the beginning of September till the end of December. While, in the second year, $C$. floridensis had three over lapping generations annually deferred from three to six powered months, the third and powers one occupied six months with periods occurred from the beginning of July to the end of December.
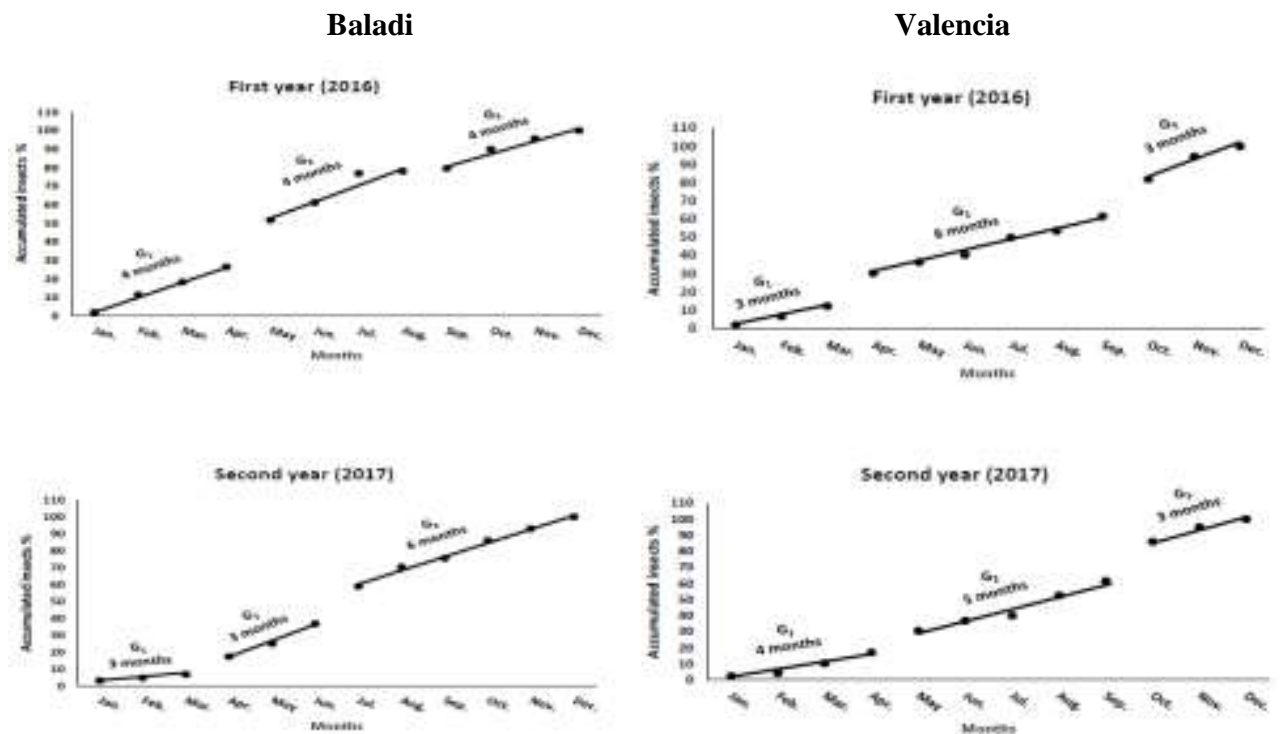

Fig. (1) Annual generations and durations of Ceroplastes floridensis Comstock under field conditions on orange trees, Baladi and Valencia varieties during (2016) and (2017) years.

Data showed in Fig. (1) indicated that during the first (2016) and second years (2017), C. floridensis had three overlapping generations annually on Valencia citrus trees variety in each of study years. Generally, the generations lasted about three to six months. The second generation and powers one was during the period extended from the beginning of April till the end of September, but it occupied the period from the first of May to the end of 
September in the first and second years of study, respectively. In general, the generations took about three to six months in both orange varieties. The first generation was during the period extended from the beginning of January mid of March. The second one occurred from the beginning of April to the mid of August. The third generation occupied the period from the beginning of September till the end of December. These results are conformable with those Salem and Hamdy (1985); Helmy et al., (1986). They reported, three generations of C. floridensis population annually occurred in mid-April, late June and early November on mandarin and in late June and mid- November on grapefruit trees in Egypt.

\section{The preferable direction for the insect:}

Results illustrated in Fig. (2) showed that in the Baladi citrus trees during the first and second years, total population density and nymph stages occurred in south western side of the trees. While, the adult females occurred in south eastern side in the first year but in the second year they occurred in north eastern side of the trees.

Baladi

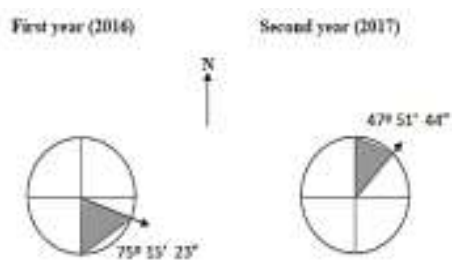

Fotmale
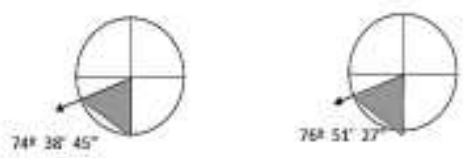

Nopupt:
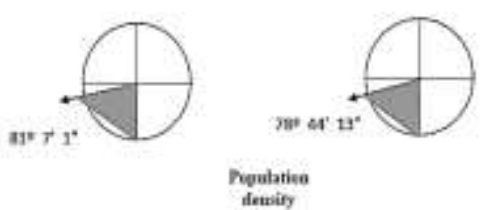

Valencia

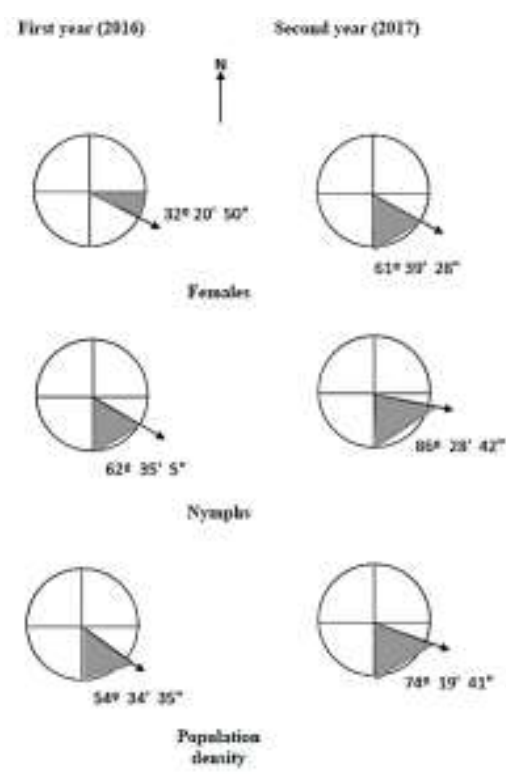

Fig. (2): The calculated directions of Ceroplastes floridensis Comstock stages on orange trees, Baladi and Valencia varieties, in Kafr Saqer district, during the two successive years (2016 and 2017). 
Data given in Fig. (2) revealed that in the Valencia citrus trees during the first and second years, the insect and there all stages preferred to be in south eastern side of the trees. Generally, the wax soft scale insect C. floridensis, concentrated in south/western-eastern side of the trees for both citrus varieties in the two successive study years. These findings were agreed with Salem and Hamdy (1985), they reported that the distribution of C. floridensis on guava trees was phototactic, therefore it was found to be most abundant on the upper section of the trees, especially on parts facing east, during July and August counts, but not the November count, the lowest populations were found in the central core of the trees.

\section{Conclusively,}

The results showed that the total number of stages of this insect were between four peaks per activity per year in the orange tree Balady and Valencia during 2016, while recorded only three peaks during 2017 on both types of orange Balady and Valencia. The total effects of weather factors in this study were based on the total number of stages of this insect during two years between positive and negative effects in both Balady and Valencia varieties, respectively.

\section{REFERENCES}

Abd El-Fatah, M.; El-Nabawi, A.; Eisa, A.A. and El-Dash, A.A. (1991). Seasonal abundance of the citrus wax scale Ceroplastes floridensis Comstock on different host plants. Menofiya J. Agric. Res., 16(1): 793- 802.

Audemard, H. and Milaire, H. G. (1975). Le pieeage carpocapse (Laspeyresia pomo- nella L.) avec une pheromone sexuelle de synthese: premiers resultats utilisables pour 1 estimation des populations et laconduite de la lutte. Ann. Zoll. Ecol. Anim.: 7 - 61.

COSTAT (2005). Version 6.311, Copyright(c), CoHort Software, 798 Lighthouse Ave. PMB 320, Monterey, CA, 93940, USA.

Ebeling, W. (1959). Subtropical fruit pests. Univ. of Cal. Div. Agri. Sci., 436 PP.

Economic Agricultural Report (2008). Central Administration for Agricultural Economic, Ministry of Agriculture, Egypt. http://www.horticultureegypt.com/hri/index.php?option

El-Agamy, F.M.; Metwally, S.M.I.; Shawer, M.B. and Metwally, M.M. (1994). The role of parasitoids in the control of Florida wax scale, Ceroplastes floridensis Comst. In Kafr El-Sheikh governorate, Egypt, J. Agric. Res. Tanta Univ., 20 (1): 58-64pp. 
El-Kassas, S. E. (1984). Effect of iron nutrition on the growth, yield, fruit quality, and leaf composition of ceded Baladi lime trees grown on sandy calcareous soils. J. Plant Nut., 7:301-311.

El-Sherbenie, Merfat, K. (2004). Role of epidemic insect predators to adjust the numerical population of harmful pests infesting guava orchards in Dakhalia Governorate. M.Sc. Thesis, Fac. Agric., Mansoura Univ., Egypt.

Farag, A.A.; Aly, N. and Abd-Rabou, S. (2014). Prediction of citrus wax scale, Ceroplastes floridensis Comstock (Hemiptera: Coccidae) populations using the two IPCC's SRES scenarios (A2 and B2) for 2050 and 2100 years. International Journal of Plant \& Soil Science, 3(6): 695-706.

Ghanim, N.M.A. (2003). Studies on some natural enemies attacking some soft scale insects. M.Sc. Thesis, Fac. Agric., Mansoura Univ., Egypt.

Hall, W. J. (1923). Further observations on the Coccidae of Egypt. Tech. ScBull., 22. Ministry Agric. Egypt.

Hassan, A. Sh. (1998). Studies on some scale insects and mealybugs infesting certain horticulture crops in newly reclaimed areas. Ph.D. Thesis, Fac. Agric., Zagazig Univ., Egypt.

Helmy, E.I.; El-Imery, S.M. and Habib, A. (1986). Ecological studies on the Florida wax scale, Ceroplastes floridensis Comst. (Homoptera: Coccoidae) on citrus in Egypt. Bull. Soc. Ent., 66: 155-165.

Hendawy, A.S. (1999). Studies on certain natural enemies of scale insects attacking guava trees at Kafr El-Sheikh governorate. Ph.D. Thesis, Fac. Agric., Kafr El-Sheikh, Tanta Univ., 145 PP..

Jacob, N. (1977). Un model matematic pentru stabilirea. Limitelor economice de tolo- ranta a atacului molilor. Fructelor in Iupte integrate. Analele I. C. P. P., Romania, 15: 179 PP.

Mahmoud, S. F. (1981). Ecological studies on the California red scale and the purple scale insect on citrus trees and the effect of some recent insecticides on them and their parasites. M.Sc. Thesis, Fac. Agric., Cairo Univ., Egypt.

Mesbah, H.A; Badr, S.A.; Khadiga. S. Mousi; Mourad, A.K. and Soad, I. Abdel-Razak (2001). Population fluctuation of the Florida wax scale Ceroplastes floredensis Comst. (Homoptera: Coccidae) infesting Ficus spp in Alexandria Governorate, J. Adv. Agric. Res., 6 (4):979-987.

Moustafa, M. (2012). Scale insects (Hemiptera: Coccoidea) infested citrus trees and their natural enemies, with a key of these pests in Egypt. Egypt. Acad. J. Biol. Sci., 5(1): 1-23.

Omar, M.A.A. (2013). Ecological studies on some species of mealybugs and scale insects of citrus trees in El-Beheira Governorate. M.Sc. Thesis, Fac. Agric., Saba Basha, Alexandria Univ., Egypt. 
Podoler, H.; Dreishpoun, Y. and Rosen, D. (1981). Population dynamics of the Florida wax scale, Ceroplastes floridensis (Homoptera: Coccidae) on citrus in Israel. 1. A partial life table. Acta Oecologica / Oecologica Applicata, 2(1): 81-91.

Salem, S.A. and Hamdy, M.K. (1985). On the population dynamics of Ceroplastes floridensis Comst. on guava trees in Egypt (Homoptera: Coccidae). Bull, Entomol. Soc. Egypt, 65:227-237.

Schneider, B.; Podoler, H. and Rosen, D. (1987). Population dynamics of the Florida wax scale, Ceroplastes floridensis on citrus in Israel. 4. Abundance, Act. Ecol. Appl., 3(8): 217-228.

Snowdon, A. L., (1990). A Color Atlas of Post-harvest diseases and disorders of fruits and vegetables: General Introduction and Fruits. CRC Press, Inc., Bocas Raton, Florida, U.S.A.,1-302.

Whiteside, J. O. (1988). Introduction, citrus trees and their fruit. In: Compendium of citrus diseases. APS Press (American Pathological Soc.), St. Paul, Minnesota, 80.

Willcocks, F. C. (1922). A survey of the more important insects and mites of Egypt with notes on life history habits natural enemies and suggestions for control. Sult. Agric. Sec., Bull., 1:169.

\section{Ceroplastes دراسات ايكولوجية على حشرة الموالح الثمعية الرخونة floridensis}

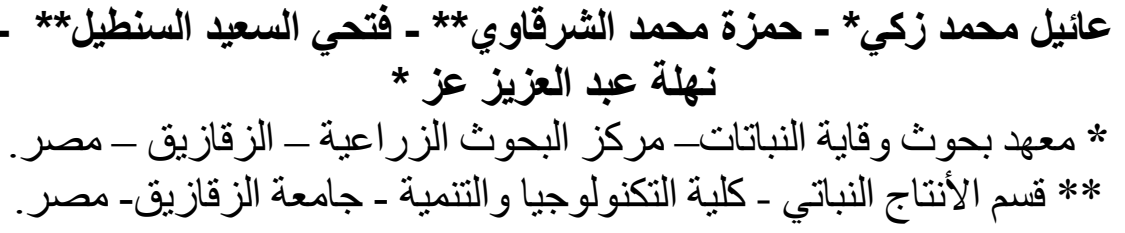

أجريت هذه الدر اسات الإيكولوجية والتطبيقية على حشرة فلوريدا الثمعية (حشرة المو الح

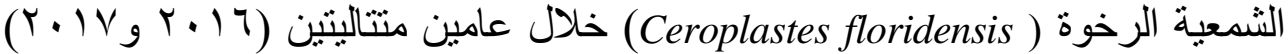

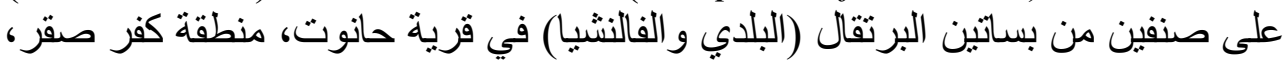

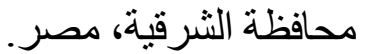

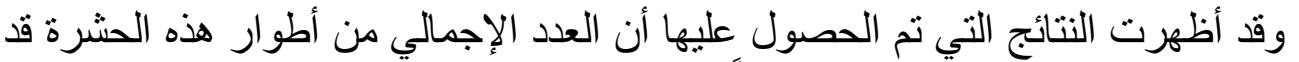
بلغ ما بين أربع ذروات للنشاط سنوياً في أصناف شجرة البرتقال البلدي وفالنشيا خلال التول 


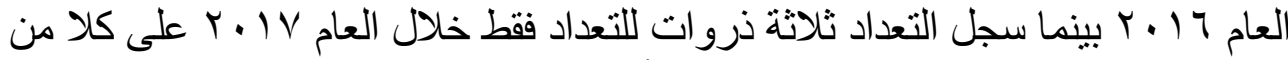

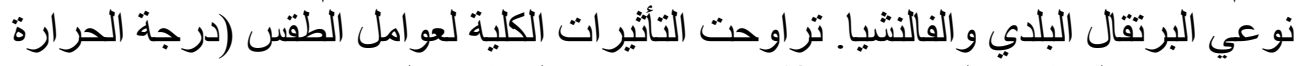

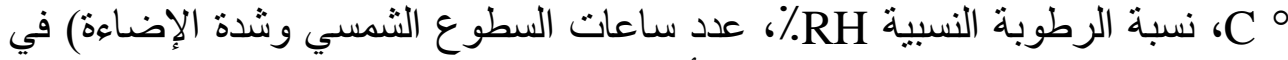

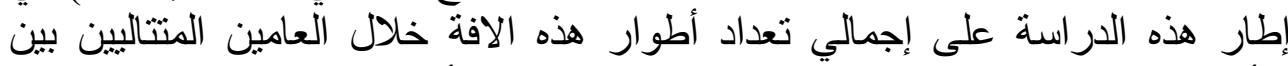

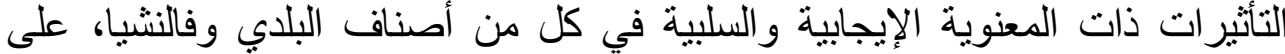

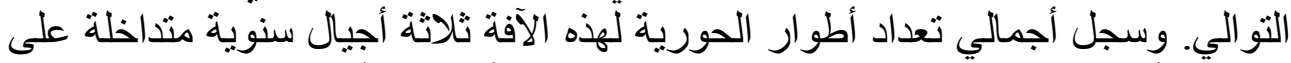

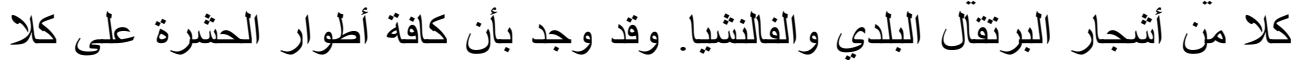

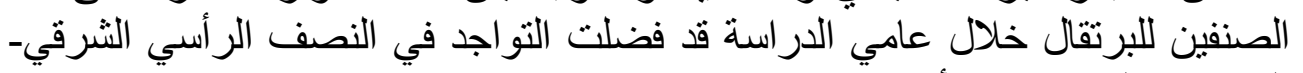

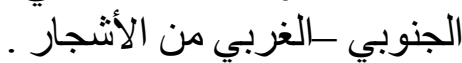
التوصية: بمعاملة هذه الاتجاهات فقط في حالة تطبيق المكافحة المتكاملة لهذه الأفة باستخدام المكاقحة بالمبيدات. 